\title{
THE IMPACT OF COLONIALISM ON THE EXISTENCE OF RELIGIONS IN BUKITTINGGI
}

\author{
Novi Hendri \\ Institut Agama Islam Negeri (LAIN) Bukittinggi, novihendri.1971@gmail.com
}

(C2021 by the authors. Submitted for possible open access publication under the terms and conditions
of the Creative Commons Attribution-ShareAlike 4.0 International License (CC-BY-SA)
license (https://creativecommons.org/licenses/by-sa/4.0/)
do) DOI: http://dx.doi.org/10.30983/fuaduna.v5i1.4199

\begin{abstract}
This article analyzes why religions other than Islam can enter and develop in Bukittinggi, a small city in the middle of the highlands of West Sumatra, primarily through the influence of colonialism. In Bukittinggi, at first, the Dutch colonial did not see Muslims as opponents. However, then the Dutch colonial political tendencies took a way to destroy any resistance from the local community by destroying the ulama and Muslims' forces and by developing non-Islamic religions as a rival. This article is using a historical approach. This article explores colonial penetration into Bukittinggi, how religious livelihood in Bukittingi before the colonialism, how people in Bukittinggi respond to a religion other than Islam, and how tolerance and religious harmony in Bukittinggi. The results showed that other than aiming for power, the Dutch colonial carried out the spread of Christianity, especially to association groups, as a means of strengthening power. Colonialist policies towards religions contradicted various principles, especially in education. They were starting from restrictions on religious teachers to the content of lessons, teaching permits, and the number of religious education institutions. The thick religion of Islam in Bukittinggi made it difficult for the Dutch colonialists to conquer Bukittinggi.
\end{abstract}

Keywords: Colonialism; History of Religion; Bukittinggi.

\begin{abstract}
Abstrak
Artikel ini menganalisis alasan kenapa agama-agama selain Islam dapat masuk dan berkembang di Kota Bukittinggi, terutama melalui pengaruh kolonialisme. Pada konteks Kota Bukittinggi, pada awalnya kolonialis Belanda tidak melihat umat Islam sebagai lawan. Namun kemudian kecenderungan politik. kolonialis Belanda menempub cara menghancurkan setiap perlawanan masyarakat lokal dengan menghancurkan kekuatan-kekuatan ulama dan umat Islam, serta dengan mengembangkan agama non Islam sebagai tandingan. Dengan menggunakan pendekatan historis, artikel ini mengeksplor bagaimana proses masuknya kolonialisme ke Bukittinggi; bagaimana agama masyarakat Bukittinggi sebelum masuknya kolonialisme; bagaimana respon masyarakat Bukittinggi terbadap masuknya agama-agama selain Islam; serta bagaimana toleransi dan kerukunan umat beragama di Bukittinggi. Hasil penelitian menunjukkan bahwa di samping tujuan kekuasaan, kolonialis Belanda melakukan penyebaran agama Kristen, terutama kepada kelompok-kelompok asosiasi, sebagai alat mengokobkan kelkuasaan. Kebijakan kolonialis terbadap agama-agama, justru bertolak belakang dengan beragam prinsip, khususnya dalam pendidikan. Mulai dari pembatasan guru agama bingga isi pelajaran, izin mengajar, dan jumlah lembaga pendidikan agama. Kentalnya agama Islam di Bukittinggi menjadikan kolonialis Belanda kesulitan dalam menaklukean Bukittinggi.
\end{abstract}

Kata Kunci: Kolonialisme; Sejarah Agama; Bukittinggi. 


\section{INTRODUCTION}

Colonialist and imperialist policies towards religions in Indonesia have occurred since the arrival of the Dutch to Indonesia. ${ }^{1}$ The arrival has resulted in propaganda in policy, character assassination against religious elites, and violence. ${ }^{2}$ These policies have changed the strategies and conditions of religious communities in various regions in the face of the Dutch colonial era.

In the context of Bukittinggi, the Dutch colonial did not see Muslims as opponents initially. However, with the unfavorable Dutch policies towards the progress of the Indonesian nation, the Dutch colonial political tendencies took a way to destroy any resistance by destroying the ulama and Muslims' forces and by developing non-Islamic religions as a rival. From within, they carry out religious conversion efforts, although this has no appeal to Muslims, and they can only attract isolated tribes, which do not yet have a religion. Meanwhile, from the outside carried out attacks against the forces of the ulama and Muslims. ${ }^{3}$

Colonialism in Indonesia started about four centuries ago by storing many things in the structure of society, even forming the reasoning of post-colonial society. A form of mimicry or hybrid reasoning in the history of our society today. Colonialism as the past is the present and future liberalism. This past is told through encounters in colonial moments. The history of colonialism and religious infidelity, especially in the aspect of purification of Islam in Indonesia, was used by orientalists such as Snouck Hurgronje to subdue the resistance of the Islamic community in Indonesia, especially the independent tarekat groups, and were considered heretical by the

${ }^{1}$ H A Suminto, Politik Islam Hindia Belanda (Jakarta: Lembaga Penelitian Pendidikan dan Penerangan Ekonomi dan Sosial, 1985).

2 Solihah Titin Sumanti, "Analisis Kebijakan Pemerintah Kolonial Belanda Terhadap Pendidikan Islam," Jurnal Ilmiah Sosialogi Agama (JISA) 1, no. 1 (July 2018): 44, https://doi.org/10.30829/jisa.v1i1.1791.

3 Jeffrey Hadler, Sengketa Tiada Putus: Matriarkat, Reformisme Agama, Dan Kolonialisasi Di Minangkabau, Tingkap, vol. 9 (Jakarta: Freedom Institute, 2008). colonialists. This group is considered to be carrying out practices that are considered heretical by puritanical Islamic groups who eventually cooperate with colonialism to straighten and repurify the Islamic community. ${ }^{4}$

Western society, with orientalism, works to bring universal culture, which is good, white, human, into black culture, which is ethnocentric, primitive, and backward by using its standards. Edward Said said that the west created the east as exotic, primitive, and mystical to show itself as rational, universal, and modern. ${ }^{5}$ In this framework, Islam is trapped in a trend deliberately created by colonialists through orientalism so that Muslims follow universality, rationality, and western-style education that carries out specific tasks to carry out continuous submission. As read by Michel Foucault, the framework of knowledge is a link between power and knowledge. ${ }^{6}$ Orientalism as a knowledge of how the west sees the east is a science that is not just a science. He is a cover for the tactical affair between the capitalists and social scientists to exercise control at the knowledge level of the colonized people. Finally, thanks to orientalism, the knowledge of the east was mastered so that colonial rule would last.

Colonial ethical politics is also read as a western effort to rationalize Indonesian Muslims and bring them into the group of modern society that is advanced, knowledgeable, and certainly superior to other cultures. The entry of European nations into the archipelago greatly influenced the religious pattern of the people of the archipelago. The control of the archipelago with its colonialism model left deep wounds for the people of the archipelago, not least for the people of Bukittinggi.

4 Ahmad Mansur Suryanegara, Menemukan Sejarah: Wacana Pergerakan Islam Di Indonesia, 4th ed. (Bandung: Mizan, 1998).

${ }^{5}$ Edward W Said, Orientalism (New York: Pantheon Books, 1978).

${ }^{6}$ Michel Foucault, Power: The Essential Works of Michel Foucault 1954-1984: Essential Works of Michel Foucault 19541984, Administrative Science Quarterly, vol. 3 (London: Penguin Books Limited, 2002). 
Before Europeans came to Bukittinggi, the people had embraced Islam and local religious beliefs. This belief was ingrained in the Minang community at that time. The belief system wrapped in the name of religion is then strengthened by its customary rules, making the Minang's people live in harmony.

However, all that changed after the entry of colonialism into Bukittinggi. The entry of colonialism into West Sumatra, especially Bukittinggi, changed the religious pattern of the Minang's people at that time. In addition, there were indeed seeds of conflict that arose at that time between indigenous peoples and Minang's cleric figures or known as Padri, West Sumatra, in 18211837. ${ }^{7}$ This war was caused by a conflict between the Padri Islamic reformers, who were in conflict with the Indigenous people. A conflict between the Padri and the Indigenous people has become an entry point for Dutch intervention. It should be understood that even though the people of West Sumatra have embraced Islam, some people still adhere to customs and habits that are sometimes not in accordance with Islamic teachings. ${ }^{8}$

This article uses the historical approach to analyze why religions other than Islam can enter and develop in Bukittinggi City, primarily through the influence of colonialism. In more detail, this article explores the process of the entry of colonialism into Bukittinggi: how was the religion of the people of Bukittinggi before the entry of colonialism; how is the response of the people of Bukittinggi to the entry of religions other than Islam; as well as how tolerance and religious harmony in Bukittinggi.

\section{THE PROCESS OF COLONIALISM IN BUKITTINGGI}

Before we discuss the entry of colonialism into Bukittinggi, we will briefly describe the history

\footnotetext{
${ }^{7}$ Hadler, Sengketa Tiada Putus: Matriarkat, Reformisme Agama, Dan Kolonialisasi Di Minangkabau.

8 Christine Dobbin, Gejolak Ekonomi, Kebangkitan Islam, Dan Gerakan Padri (Jakarta: Komunitas Bambu, 2008).
}

of Bukittinggi. Bukittinggi began to stand with the arrival of the Dutch. They then established a stronghold in 1825 during the Padri War on one of the hills contained in this city. This place is known as the Fort de Kock and a resting place for Dutch officers in their colonies. Then during the reign of the Dutch East Indies, this area was constantly enhanced its role in the state administration, which later developed into a Staatsgemeente, and also served as the capital city of the Dutch East Indies Afdeeling Padangsche Bovenlanden and Onderafdeeling Oud Agam. ${ }^{9}$

During the Japanese occupation, Bukittinggi became the center of control of the military government for the Sumatra region, even to Singapore and Thailand. The city became the 25th military commander of the Kempetai, under Major General Hirano Toyoji. Then the city changed its name from Staatsgemeente Fort de Kock into Bukittinggi Si Yaku Sho which the scope expanded into some nagari like: Sianok Anam Suku, Gadut, Kapau, Ampang Gadang, Batu Taba dan Bukit Batabuah. Now, Nagari is under the Agam district governance. After Indonesia's independence, Bukittinggi was chosen to be the capital of the province of Sumatra, with the governor Mr. Teuku Muhammad Hasan. Then Bukittinggi was also designated as a city government area based on the Decree of the Governor of Sumatra Province Number 391 dated June 9, $1947 .^{10}$

During the struggle for Indonesia's independence, Bukittinggi played a significant role. On December 19, 1948, the city was appointed as the capital of the state of Indonesia after Yogyakarta fell to the Dutch or known as the Emergency Government of the Republic of Indonesia (PDRI). At a later date, this event was designated as Hari Bela Negara, based on the

\footnotetext{
${ }^{9}$ Hadler, Sengketa Tiada Putus: Matriarkat, Reformisme Agama, Dan Kolonialisasi Di Minangkabau.

${ }^{10}$ Elizabeth E Graves, Asal Usul Elit Minangkabau Modren Respon Terbadap Kolonial Belanda Abad XIX/XX Terj. Novi Andri Dkk (Jakarta: Yayasan Obor Indonesia, 2007).
} 
Decree of the President of the Republic of Indonesia on December 18, 2006.

The Dutch first landed in Padang in 1818. They tried to get a position in the West Sumatra area by involving themselves in conflicts between traditional and religious groups. Even the Netherlands actively helped indigenous groups suppress religious groups in the Padri War of 1821-1837. ${ }^{11}$ The Dutch carried out efforts to suppress religious groups around Agam and Pasaman, which were followed up by making a friendship agreement with the Penghulu Kurai Limo Jorong, which contained cooperation and joint efforts of the indigenous groups (represented by the penghulu) with the Dutch in suppressing religious groups. This agreement was held in 1820. The agreement's results were followed by the Penghulu Kurai Limo Jorong agreement that the Dutch could build a fort in this area in 1825-1826. At that time, Captain Bauer founded the Sterreschans Fort, which was later known as the Fort De Kock in Bukit Jirek. This fort became the forerunner of the control and expansion of Dutch power in Bukittinggi, Agam, and Pasaman. Dutch control continues to Bukit Sarang Gagak, Bukit Tambun Tulang, Bukit Cubadak Bungkuak, dan Bukit Malambuang which is the development area of the Bukittinggi Zoo. ${ }^{12}$

In the areas controlled by the Dutch, several offices, civil government houses, meeting houses, grave complexes, markets, transportation facilities and infrastructure, schools, and recreational facilities were established. To strengthen the position of the Dutch, they used traditional Minangkabau leaders. For Bukittinggi and Agam, which is called Staatsgemeente Fort De Kock leads by a Controller occupied by the Dutch. They have a close relationship with the community, especially the traditional leaders in

${ }^{11}$ Dobbin, Gejolak Ekonomi, Kebangkitan Islam, Dan Gerakan Padri.

12 Dobbin.

${ }^{13}$ Graves, Asal Usul Elit Minangkabau Modren Respon Terhadap Kolonial Belanda Abad XIX/XX Terj. Novi Andri Dk.k. nagari around Agam, Bukittinggi. People call it "Tuanku Kumentur", he is feared, has the right to issue instructions that the people must carry out, and issue laws for violators. ${ }^{13}$

In the era before the Padri Movement and War, religious groups as intellectuals at that time, because they understood writing and reading, only played a role as educators of the younger generation and guides in the community's spiritual life. Any practical power did not accompany his position and function as a community clergyman. As a family and tribe member, a cleric may very well use the title of his family or tribe. However, because his field of expertise and duties lies in the field of education, in the field of government, he is silent. The titles entitled to ulama are pandito, khatib, imam, or syekh, depending on their expertise and authority as a religious teacher and community spiritual guide. ${ }^{14}$

As an educated group in Minangkabau, the ulama experienced mental stress because they felt they did not get a place and appreciation in the hierarchical structure of government in the nagari. The feeling of dissatisfaction develops and expands, often due to the actions and actions of the group of penghulu, who has a crossing path with religious guidelines and "syaria". The abuse of power by groups or individuals in power or drunk on power has always happened in history, not bound by time and place. The resulting reaction always occurs from time to time and throughout the world.

In this connection, the reaction that emerged from the ulama circles, especially the young ones, at the end of the 18th century and the beginning of the 19th century in Minangkabau was not unique to Minangkabau. Nevertheless, it can be considered a logical historical development of a disaffected group. This feeling of dissatisfaction

14 Idrus Hakimy, Rangkaian Mustika Adat Bersandi Syarak Di Minangkabau, 6th ed. (Bandung: Pt. Remaja Rosdakarya, 2004). 
among the young Minangkabau ulema, with the help of most of their students, was known in Minangkabau history as the Padri Movement, which later erupted into a civil war, called the Padri War (1821-1837). ${ }^{15}$

The opinion about the movement that will determine the course of Minangkabau history in the following centuries is merely a conflict between the adat and the religious, the penghulu and the ulama, is too narrow. Even the ulama came from and grew up in a traditional environment, as individuals obeyed custom. The essence of the movement for renewal and reform of the Minangkabau community structure at the beginning of the 19th century was because a group of people who considered themselves competent did not get a proper place and position in the political constellation in Minangkabau at that time.

Although the Padri Movement, which sparked the Padri War in Minangkabau was crushed with the help of Dutch weapons, as an influential and powerful ideology in the Minangkabau area, which it controlled for more than a generation, it did not disappear entirely with the defeat suffered by the Padri. As ulama, they continue to monopolize the education and spiritual development of the Minangkabau community. The changes and reforms of the government system that they had practiced persisted and continued after the Padri War was over. Religious groups are included in customary densities, their opinions and voices are heard and implemented. The title Tuanku, which was previously monopolized by the penghulu as the sole power holder in his family and tribe and as a member of the governing council of the nagari republic, was also used for the ulama. Depending on the size of the influence and authority possessed, a scholar has the title Tuanku, such as Tuanku Imam or Tuanku Sheikh. ${ }^{16}$

\footnotetext{
${ }^{15}$ Hakimy.

16 Graves, Asal Usul Elit Minangkabau Modren Respon Terhadap Kolonial Belanda Abad XIX/XX Terj. Novi Andri Dk.k.
}

During the Japanese occupation (19421945), the ruler emphasized the position and role of the ulama rather than the penghulu. The ulama's movement is limited as the leader, and the Dutch created their position as anti-colonial. They were opposed to the penghulu, as ninik-mamak who helped the Dutch and were branded as "collaborators of the colonization."

\section{RELIGION OF PRE-COLONIALISM IN BUKITTINGGI CITY}

In the archipelago's country called Indonesia, there have been various religions: Hinduism, Buddhism, and various local beliefs long before becoming a nation-state. The tendency of syncretism that mixes various existing religions also becomes its color, especially on the island of Java. Academically, discussing religious issues in Javanese palaces by religious elites is also a familiar tradition. The pattern of inter-religious relations in the past was influenced by the colonial government's political system and religious politics. Each is left in an antithesis relation, competition. Meanwhile, the colonial government carried out religious politics, which only tended to dogma, not ethics. As a result, religious life loses its inspiration for its people. By the colonial ruling elite, inter-religious communication was controlled in such a way that it did not run freely and openly. In the context of Minang in general and Bukittinggi in particular, almost $97 \%$ of the population is Muslim. ${ }^{17}$

There are various opinions regarding the beginning of the entry of Islam to Bukittinggi. Some say Islam entered the Minangkabau area around the 7th century AD. Other opinions said it was in the 13th century. However, what is clear from various kinds of literature and historians agree that the spread of Islam is through three routes: First, through trade. Because the Minangkabau area is not only located on a strategic

17 Febri Yulika, Epistemologi Minangkabau: Makna Pengetahuan Dalam Filsafat Adat Minangkabau (Yogyakarta: Gre Publishing, 2012). 
route in terms of trade, it is also the largest producer of agricultural commodities and spices on the island of Sumatra, namely pepper and nutmeg. Persian and Gujarat traders were merchants who had intense trade relations with Minangkabau traders, especially in the eastern part. The path taken is the Kampar Kanan River, Kampar Kiri, Batang Hari River and Dareh River. They have been doing this interaction since the 7 th century $\mathrm{AD}$. In this regard, in general, they have also embraced Islam as well as acting as da'i. This shows that Islamic broadcasting at that time had taken place even though it had not been planned and programmed. ${ }^{18}$

In this context, many Minang's figures are interested in the religion they profess, let alone the practice of life. One of the things that encourage them and the ease with which they accept Islam is that its teachings are simple and easy to understand. Moreover, the culture and traditional philosophy adopted and its open nature add to the encouraging atmosphere for the development of Islam in the region. The broadcasting of Islam in this period was stopped because it was hindered by the actions of the Chinese T'ang Dynasty, who felt that the Umayyad Caliph threatened their economic interests in eastern Minangkabau. This situation lasted approximately 400 years. Based on the description above, it can be understood that the development of Islam in this decade was carried out through a cultural approach, namely under the social and cultural conditions of the Minang's people.

Second, Islamic broadcasting at this stage took place at a time when the west coast of Minangkabau was under the influence of Aceh (1285-1522). As people who first converted to Islam, Acehnese traders also played a role as missionaries. They are active in broadcasting and developing Islam in the coastal areas, where they trade, especially in areas under the influence of
Aceh (Samudera Pasai). Since then, Islamization in Minangkabau has been carried out on a large scale and planned. It takes place in the 15th century AD. ${ }^{19}$

Apart from that, a Minangkabau son, Burhanuddin, the son of Koto Padang Pariaman, had also converted to Islam. He then went to Aceh to study Islamic knowledge from Sheikh Abdurrauf. Upon his return from Aceh, he intensively began to teach Islam in his area, especially in Ulakan. It turned out that what he was trying to do was well received by the surrounding community, and even his students also came from various parts of Minangkabau. In a relatively short time, Ulakan became crowded with people to study Islam more deeply. Since then this place is still crowded with Muslims from all over the country, especially in the month of Safar. Not surprisingly, through Burhanuddin's students, Islam grew to the darek area. In connection with this, there is a traditional proverb that says: Syarak mandaki adat manurun. Islam began to be developed from the coastal areas to the interior, while adat originated from darek and then developed to the overseas areas, including the coast. $^{20}$

Third, Islam from the west coast continued to climb to the darek area. In this period, the Pagaruyung kingdom is the center of the Minangkabau government still adhered to Buddhism. However, most Minangkabau people have embraced Islam. The influence of Islam is visible in their daily lives. This situation for Pagaruyung is just waiting for the time to embrace Islam. In the mid-17th century, all gold trading centers and villages where most of the population was gold traders had embraced Islam. Sumpur Kudus then got the title as the Mekkah Darat. Meanwhile, other gold centers such as Talawi and Padang Ganting also became Muslims. Similarly, the Hindu-Buddhist centers around Saruaso and
18 Hamka, Antara Fakta Dan Khayal Tuanku Rao (Yogyakarta: Suara Muhammadiyah, 2008).

${ }^{19}$ Hamka.
${ }^{20}$ Yulika, Epistemologi Minangkabau: Makna Pengetahuan Dalam Filsafat Adat Minangkabau. 
Pagaruyung embraced Islam when the royal family moved there. ${ }^{21}$

For the Minangkabau Highlands, there is still another way for Islam to enter this area. This is the path that is suitable for both Islamic thought and Minangkabau thought. In that way, villages are involved in the overall Islamic system even though the village itself may not be a Muslim community. A critical aspect of Minangkabau village life is the surau, the house where young people live after puberty. There are many agricultural villages in Minangkabau and they are not related to the gold trade, their relationship to Islam is of two kinds: First, the affiliation of this new religion with family and tribal systems and; second, the relationship between Islam and the village community as a whole. This second relationship is more challenging to implement. Agricultural life is continuous in the rhythm of planting and reaping. The system is very much in line with pleasing spirits and consulting psychics.

It seems that Islam has nothing to offer here. It is not surprising that at the beginning of the 19th century, there were still villages that had no connection with Muslim beliefs. So, Islam does not impact the community level but only at the tribal level. As for what is mentioned with Sumpur Kudus, Padang Ganting and Saruaso, this is what will later be known as Rajo Tigo Selo. Three kings are cross-legged or enthroned, namely, the Indigenous King in Buo, Rajo Ibadat in Sumpur Kudus, and Rajo Alam in Pagaruyung. Raja Tiga Sila is the highest institution in the Pagaruyung kingdom which in traditional tambo is called Limbago Rajo or Yang Dipertuan, namely those who are mastered together.

In the jahiliyah era, the Minangkabau king was only a symbol. There is absolutely no feudalism. At the highest, only the aristocracy existed in the government of Koto Piliang. After Islam took part in composing adat, the arrangement was preserved in a new form. So

${ }^{21}$ G.F Pijper, Beberapa Studi Tentang Sejarah Islam Di Indonesia 1900-1950 (Jakarta: Universitas Indonesia, 1985). historically, before the entry of various religions into Minangkabau, the community in addition to obeying customary regulations, had also adhered to pre-religious beliefs, both in the form of animism and dynamism, so that they received religious influences from outside. The first religions to enter the archipelago were Hinduism and Buddhism. In the 6th or 7th century AD. Both religions have been on the island of Sumatra. ${ }^{22}$

Indeed, not much is known about the Hindu-Buddhist era in Minangkabau. However, it has been confirmed that in 1356 Adityawarman founded a Buddhist monastery near Gombak Hill. The monastery became a gathering place for youths to study sacred knowledge. This example is undoubtedly an ideal solution to an undeniable social problem. Therefore, in certain villages Islam arranged learning facilities based on a surau from pre-Islamic times. Hence, this is because, in the early centuries of the entry of Islam, Muslim brotherhood emerged in response to the general need to have a closer relationship with God.

This method is considered better than the dry laws presented by official Islamic scholars. Adherents of this brotherhood are also called Sufis. They pursue the thoriqoh determined by a teacher or sheikh, whose knowledge is the primary source of information. The tarekat and its schools can fit into the existing surau system in Minangkabau without any friction.

The main factor in the success of the conversion was the ability of the Sufis to present Islam in an attractive package, particularly by emphasizing conformity with Islam or continuity rather than changes in local religious beliefs and practices. By using Sufism as a category in MalayIndonesian literature and history. In addition, Minangkabau's traditional values and norms contained in various forms of linguistic expression such as proverbs, rhymes, or even oral stories passed down and spread orally before Islam penetrated into Minangkabau also had similarities

${ }^{22}$ Karel A. Steenbrink, Beberapa Aspek Tentang Islam Di Indonesia Abad Ke-19 (Jakarta: Bulan Bintang, 1984). 
about the teachings of Islam. in the field, namely both prioritizing good manners and shyness among others, as the traditional proverb says, "Mamakai raso jo pareso, manaruah malu jo sopan". ${ }^{23}$

The relationship between Islam and adat in Minangkabau is very complex, and in some instances, it is not uncommon for conflicts and tensions between the two. However, even though there is a conflict between Islam on the one hand and adat on the other, it cannot be seen as a form of tension between two different "worldviews" but as a unit in a system as a whole.

The link between adat and Islam in Minangkabau, as written by Buya Hamka, states that in the regulation of Islamic Fiqh Law, "urf and adat" in every country are recognized as a reality. Islam arrived in a land that has been ordered system. With the arrival of Islam, it added to the firmness of the existing regulations. Therefore, the customary structure of the government of Koto Piliang and Bodi Caniago was left intact, as well as the symbols of the greatness of the Minangkabau people, namely, the names of Datuk Perpatih Nan Sebatang and Datuk Ketumanggungan.

The stages that are passed to realize the connection between adat and syara' so that both run in an integrated manner. According to Syarifuddin, there are at least three stages. First, adat and syara' run independently within boundaries that do not affect each other. The Minangkabau people practice their religion in aqidah and worship but still adhere to customary norms, especially in aspects of social life as the saying goes: Adat basandi alur dan patut, syara' basandi dalil. Second, between adat and syara', each other demands rights without shifting the position of the other party's positions: Adat basandi syara', syara' basandi adat. That is, between adat and syara' need each other and cannot be separated. Based on this meaning, a Minangkabau at the time of carrying out religious teachings by itself has carried out customary guidelines. Likewise, when carrying out traditional teachings, they have also worked on religion. This is due to the integration of custom with religion or custom is integrated into religion. Third, it is marked by conflicts between religious leaders who want the purification of Islam and traditional leaders who want to maintain traditional values in their entirety. The conflict occurred because of dissatisfaction among religious leaders towards implementing Islamic teachings, which were considered not pure from practices outside the teachings, such as animism and dynamism. So qualitatively, the teachings of religion have not been carried out purely even though quantitatively there are many followers of Islam.

Some religious leaders give excessive tolerance to traditional leaders also contributed to the conflict. This Islamic purification movement is known as the Padri movement. The conflict ended with a consensus reached between traditional leaders and religious leaders, later known as the Bukik Marapalam Charter whose essence is Adat Basandi Syara', Syara' Basandi Kitabullah, Syarak Mangato Adat Mamakai. Through this consensus, customary law is carried out in everyday life as long as it does not conflict with sharia law. ${ }^{24}$

Based on the description above, it can be seen that the concept of God epistemologically in Minangkabau traditional philosophy must be seen in two timescales, namely before and after Islam entered the Minangkabau region. Before Islam came, the concept of God was interpreted in terms of cultural religion through empirical experience, namely, nature developed into a teacher. In their belief after returning to the God, they liken it to the sound of the proverb, hiduik dikanduang adat, mati dikanduang tanah (life is conceived by custom, death is conceived by soil). After embracing Islamic religious beliefs, their belief in God is something absolute, so the existence of God is in the highest position. We can get this 
from this traditional proverb, hiduik baraka, mati bariman.

\section{THE RESPONSE OF THE BUKIT'TINGGI COMMUNITY TO RELIGIONS OTHER THAN ISLAM}

As the author has explained above, that Minangkabau, especially Bukittinggi, is identical to Islam. This means that there is a cult and even an identity for the community, that every time he mentions the word Minang, he automatically becomes a Muslim. Before the Europeans arrived in Indonesia, the people had embraced Hinduism, Buddhism, and Islam. The existence of these religions is supported by the establishment of kingdoms with Hindu-Buddhist and Islamic patterns. For several centuries Hindu, Buddhist, or Islamic culture has been embedded in the hearts of most Indonesian people. The emergence of efforts to expand the power of the colonials was followed by efforts to spread Christianity, but in the early stages, it was not easy to develop. ${ }^{25}$

During the colonial period, there were indeed attempts by the Dutch East Indies government to hinder the pace of development of other religions, especially Islamic educational institutions. However, the ulama commited to spread Islam so that the diaspora of Islam was not so disturbed by Christianity. Likewise, with Hindus and Buddhists who are steadfast in their beliefs. Because of this, Christianity then developed more in areas that Islam and other religions did not touch. Thus, there was never a war against the Portuguese or the Dutch motivated by religious issues. The reaction of the Indonesian people towards the imperialist colonialists was more due to the attitude of arbitrariness, injustice, and the trampling of humanity. ${ }^{26}$

Supervision, discipline, control, and recording of Muslim worship activities were part of the political character of colonial religion. In

25 Bakhtiar, Ranaah Minang Di Tengah Cengkeraman Kristenisasi (Jakarta: Bumi Aksara, 2005).

${ }^{26}$ Yulika, Epistemologi Minangkabau: Makna Pengetahuan Dalam Filsafat Adat Minangkabau. principle, the politics applied by a Snouck is the politics of secularism and religious liberalism. The mission of marginalizing religion from political affairs was deliberately designed by Snouck so that the critical power of Muslims can be regulated and suppressed. The Dutch government's religious politics is haunted by excessive suspicion of Muslim activities. In this context, the Netherlands as a representation of the West is a subject that grips and crams the culture and thoughts of the colonized people from various secular and liberal doctrines. As a result, the critical power of the people is depressed. ${ }^{27}$

Secularism and liberalism, which can more simply be said to be movements that map out religious ideology and state ideology and free positions, institutions, religious symbols from the participation of social criticism, are the grand design projects of imperialism's religious politics to curb abuse of the application of religious teachings. The implication of the application of politics is the sterilization or taming of excessive political participation in the name of religion. Some examples, in the context of the development of Islam in Indonesia, are the creation of the terms Urban Islam and Village Islam, Modern Islam and Traditional Islam, Liberal Islam and Radical Islam, Fanatic Islam and Moderate Islam, as well as several chosen terms, colors, and faces of Islam in this country.

Snouck's politics, which focused on separating the religious practices of Muslims, greatly influenced the mentality of later Muslims' beliefs. Material categorization from ubudiyah affairs, muamalah, to political Islam movements became the new strategy of the colonial government to control this country. Snouck, learn about Islam in Mecca, believes that ubudiyah and muamalah for Muslims are very sensitive to be suppressed. Therefore, he also suggested to the Dutch government to supervise and control the

27 Zikri Fadila, Penerbitan Minangkabau Masa Kolonial: Sejarah Penerbitan Buku Di Fort de Kock (Bukittinggi) 1901-1942 (Gre Publishing, 2018). 
activities of Muslims that lead to political activities. On the contrary, it frees the people to carry out ubudiyah and muamalah activities. To make his project a success, Snouck also formulated a war strategy, which has historically been referred to as the split-bamboo political style. Namely, the strategy of separating the activities of Muslims from matters of worship, muamalat, and politics. ${ }^{28}$

The religious politics applied by Snouck during the colonial period greatly influenced the religious pattern of the Bukittinggi people. Islam, which was originally the only religion that was embraced and openly accepted by the people of Bukittinggi, especially the marginalized communities, is now growing in religions other than Islam, such as Christianity, in Bukittinggi. The response of the people of Bukittinggi to religions outside of Islam today is very diverse. Some openly accept a religion outside of Islam, but there are still many who openly reject the religion outside of Islam. To the point of carrying out terror in the name of religion against people who have beliefs outside of Islam.

Reflecting on the history of Minangkabau development, every Minangkabau person must be identical with his Islam so that the development of Christianity in Bukittinggi was much influenced by people who came from outside Bukittinggi. The early development of Christianity in Bukittinggi brought by the colonialists caused many conflicts in the Minang community. However, as time goes by, conflicts in the name of religion are rarely found in Bukittinggi today. The community has begun to be open to accepting Christians amid the Minang Islamic community, which is hold adat basandi syara', with a note that Christian groups must respect and respect the religion of the Bukittinggi people. Furthermore, the Christian community must submit and obey the customary laws and rules applied by the Bukittinggi regional government.

${ }^{28}$ Steenbrink, Beberapa Aspek Tentang Islam Di Indonesia Abad Ke-19.

\section{RELIGIOUS TOLERANCE AND HARMONY IN BUKITTINGGI CITY}

Apart from being a union of various tribes, cultures and customs, Indonesian also consists of various religions. Thus, to create national unity and integrity, religious harmony is one of the crucial pillars that need to be improved. Bukittinggi, commonly known as the "Kota Jam Gadang" and "Tourism City" with 25,239 Km2, is one of the seven cities in West Sumatra Province. The position of Bukittinggi is geographically located between 100020' - 100025' east longitude and 00016' - 00020' south latitude with an altitude of about 780 - 950meters above sea level. The area is approximately 25,239 $\mathrm{Km} 2$. This area is 0.06 percent of the area of West Sumatra Province. The distance of Bukittinggi City from the capital city of West Sumatra Province is about $90 \mathrm{~km}$, by going through uphill and winding roads, especially in the natural tourist location of the Anai Valley, which is famous for its waterfalls. ${ }^{29}$

Bukittinggi consists of three sub-districts and 24 villages, while the population of Bukittinggi based on 2016 BPs data is 122,656 inhabitants. The areas that become the periphery of the Bukittinggi City are all under the government of Agam Regency. The largest sub-district in terms of area is Mandiangin Koto Selayan Sub-district, which is $12.156 \mathrm{Km} 2$, with a percentage of $48.16 \%$ of the sub-district area and has nine villages, then followed by Guguak Panjang as the second-largest sub-district, which is $6.831 \mathrm{Km} 2$ with a percentage of $27.707 \%$ of the sub-district area and has seven villages. The smallest sub-district is Aur Birugo Tigo Baleh, with an area of $6.252 \mathrm{Km} 2$ and the percentage of the sub-district area is $24.77 \%$ which has eight villages. ${ }^{30}$

The border position of Bukittinggi City in the north is bordered by Nagari Gadut and Kapau, Tilatang Kamang District, Agam Regency. To the

${ }^{29}$ BPS Kota Bukittinggi, "Bukittinggi Dalam Angka 2016" (Bukittinggi, 2016).

30 Bukittinggi. 
south, it is bordered by Taluak IV, the tribe of Banuhampu District, Agam Regency. In the west, it is bordered by Nagari Sianok, Guguk, and Koto Gadang, District IV Koto, Agam Regency. And in the east is bordered by Nagari Tanjung Alam, Ampang Gadang District IV Angkat, Agam Regency. The location of Bukittinggi is very strategic when viewed in terms of cruising by land transportation between the provinces of West Sumatra and Riau.

Bukittinggi is the entrance gate from Pekanbaru and from North Sumatra to cities in West Sumatra Province. The distance from Bukittinggi City to Pekanbaru City is $221 \mathrm{~km}$ and can be reached for \pm 5.5 hours by private transportation, while the distance to Padang City is $91 \mathrm{~km}$. As a crossing area, Bukittinggi has become a multi-ethnic and religious city. Various kinds of religions and cultures exist in Bukittinggi, such as Islam, Christianity, and Confucianism. However, the most striking development of religion today in Bukittinggi is the development of Christianity. Especially Batak and Nias Christians. Almost 65\% of the population of Bukittinggi are immigrants. The inhabitants come from outside West Sumatra and within the province of West Sumatra, such as Javanese, Batak, Nias, and Malay.

The current population of the Christian Batak in Bukittinggi City is 40,435 people, and Nias Christians about 53,586 people across various sub-districts in Bukittinggi City (BPS Kota Bukittinggi, 2016). In the last ten years, the rapid population growth of Bukittinggi, especially residents who come from outside the Provinces of West Sumatra, Batak, and Java, has made Bukittinggi rich in differences and religious rituals, and inter-ethnic and religious interactions possibly have a crossing path.

Like other provinces in Indonesia, the population of West Sumatra Province, which also consists of various ethnicities, tribes, cultures, and religions, naturally cannot avoid the possibility of

${ }^{31}$ Yulika, Epistemologi Minangkabau: Makna Pengetabuan Dalam Filsafat Adat Minangkabau. negative impacts related to the flow of modernity, which inevitably has to be faced by the people. Thus, the possibility of conflict between different groups, especially among different religions, potentially occurs.

The existence of a kind of idm among the Minang community, "adat basandi syara', syara' basandi Kitabullah", makes religion in the Minang's realm a sensitive matter and religions other than Islam are a problem. Such religious attitudes are vulnerable to conflicts between religious communities. The implications of such an attitude include, among other things, that according to Minang's culture, children or families who leave Islam, are banished forever, must leave Bukittinggi, and are not recognized as a family according to adat. The application of this culture in a family way can stretch relations between families because of different religions. ${ }^{31}$

The diversity of customs and cultures that contain noble values in people's lives, which we regard as the treasures of the nation's wealth that need to be preserved, in connection with the swift currents of modernization lately, tend to ignore religious harmony in West Sumatra. In terms of cultural values, it is not uncommon that these are in line with the religious teachings of our nation, so that it is potential for efforts to increase religious harmony through cultural pillars. ${ }^{32}$

The dynamics of the religious life of the people in West Sumatra, especially Bukittinggi, cannot be separated from the presence of other religious people in the region and the diversity of ethnicities and tribes with their respective cultures, especially those with religious nuances. Meanwhile, the West Sumatra region, famous for the Minang's realm, gives its religious color and nuance to the Minang's community and immigrant communities. Immigrants who are religious other than Islam will experience adaptation in society and religious life.

32 Irhas Fansuri Mursal, "Surau Dan Sekolah: Dualisme Pendidikan Di Bukitinggi 1901-1942," Titian: Jurnal Ilmu Humaniora 2, no. 1 (2018): 100-115. 
Moreover, Minang's customs and culture are very thick with the values of Islamic teachings. Therefore, it is understandable that the term Minang people is synonymous with Islam, while West Sumatran has the connotation of "not necessarily Islam". The actualization of the religious life of the Minang's people as the majority tribe in Bukittinggi, which is full of Minang's customs and culture based on Islamic teachings, however, gives its own nuances in relating and socializing with people of other religions in Bukittinggi, even with other ethnicities or tribes even though they are of the same religion.

On the other hand, immigrants who do not or do not understand the conditions of Minang's customs and culture if they do not adapt will experience problems, even under certain conditions, it can cause disharmony in social relations, which tends to cause conflict in people's lives. The existence of various cases of social conflict and conflict with religious nuances in Bukittinggi with various backgrounds shows that, among others, the unpreparedness of the immigrants and residents in this case, the Minang's people in facing the reality of the existing diversity. ${ }^{33}$

However, the potential for existing conflicts can be eliminated, reduced and even neutralized if possible by strengthening and more effectively and optimizing the integration potentials that exist in society. Through this method, it is hoped that cases of social conflict and social conflict with religious nuances in Bukittinggi are hoped not to be repeated, at least they can be reduced. However, in the end, it all depends on each individual and group of religious people, religious leaders and leaders, and local government officials, how great their respective intentions are in contributing to efforts to increase religious harmony. With the spirit of togetherness decorated with a more tolerant attitude, a more harmonious religious life may be realized.
As social beings who constantly interact with one another, the consequences of this interaction give rise to two possibilities, both conflict, and integration (harmony). Johnson, quoting Durkheim's opinion, states that society is basically divided into two types; first, the society with mechanical solidarity, and second, the type of organic solidarity society. So, in this case, restitutive law in the form of law that maintains and protects the complex interdependence between individuals in society is indispensable in realizing harmony.

Gertz explained that conflict could be suppressed so that social integration can be created through the following four things: first, the feeling of belonging to one culture, including the increasing importance of the values of nationalism. Second, the emergence of various individuals or groups of mixed types that function as intermediaries so that there is a balance in the structure. Third, general tolerance based on a contextual relativism that considers specific values according to the context. Fourth, the steady growth of social mechanisms leads to plural and non-syncretic forms of social integration in which people with radically different social views and fundamental values can get along well enough with one another to maintain to keep society functioning.

Meanwhile, according to Hendropuspito (1983), the factors that support the occurrence of religious harmony are:

\section{a. Aspects of religious teachings}

Religious teachings are basically universal, contain elements of love, help, love each other, and be fair to others. The function of religion is to foster brotherhood, where each religion succeeds in uniting its people regardless of racial and cultural differences into a large community so as to create peace and tranquility. The desire to create harmony on this earth can be done with a religious approach. ${ }^{34}$ In Islamic

34 Novi Hendri and Hardi Putra Wirman, "The Radical Islamic Movements in West Sumatra: An Early 
teachings it is explained that Islam does not forbid its people to establish brotherhood as fellow human beings, between Muslims and non-Muslims, as long as they respect Islamic rights.

Meanwhile, in Christianity, the believers carry out the teachings of compassion and love that are intended not only for their people but for all humans. So it can be understood that every religion has teachings that condemn evil deeds, stupidity, laziness and inhumane acts. Thus, basically living in harmony and harmony is the dream of every religious believer.

\section{b. Aspect of social and Culture}

1. Formation of Interfaith Organizations

Various religious organizations initiated by the Ministry of Religion and religious leaders or leaders in a forum for inter-religious relations, consisting of the Indonesian Ulama Council (MUI), the Indonesian Council of Churches (DGI), the Supreme Council of Bishops of Indonesia (MAWI), Parisada Hindu Dharma Center (PHDP) and the Indonesian Buddhist Trust (Walubi). In some areas, interfaith organizations also thrive, where these organizations were formed on the initiative of funding and infrastructure support by the government. These organizations include the Indonesian Conference on Religion and Peace (ICRP) based in Jakarta. In Medan also established an interfaith organization in the form of the Interfaith Communication Forum (FKPA). In Palembang, the South Sumatra Community Communication Forum (Fokuss) was also established. Meanwhile, in Banjarbaru, South Kalimantan, the Interreligious Communication Forum (FUMA) was established.

Investigation and Mapping," Islam Realitas: Journal of Islamic \& Social Studies 6, no. 1 (2020): 100-118.

35 Reni Dian Anggraini, "Perlawanan Dan Pembebasan Kolonialisme Pada Tarekat Qadiriyah Wa Naqsyabandiyah (1888-1903)," Islam Transformatif: Journal of Islamic Studies 4, no. 2 (December 2020): 135, https://doi.org/10.30983/it.v4i2.3346.

\section{Local Wisdom}

Local wisdom for the people of an area grows because of local customs that have relations between religious adherents so that harmony is created. In Java, for example, there are wisdom values in Siri customs and in Minangkabau in the form of local wisdom values in togetherness, in customary values in the form of, barek samo dipikua and ringan samo dijinjing. Social harmony and harmony in society can basically be realized if social processes and social actions can work together in building a community. Therefore, social processes have functions that emphasize the goal of realizing social and community life with a balance or equilibrium pattern among its elements to produce harmony in society. Harmony can be realized if each component in society can carry out its function in life. ${ }^{35}$

So far, especially in Bukittinggi, interreligious conflicts can still be suppressed, due to the high tolerance shown by religious communities in Bukittinggi, especially between Islam and Christianity. Although there are indeed sparks of conflict that have arisen due to these religious issues. ${ }^{36}$

3. Pedati

Bukittinggi has the potential of an exciting location to be seen by tourists who come, but there are also various arts and cultures that color people's lives. The Festival of Arts, Culture, Trade and Industry Exhibition (Pedati) is an annual event held by the government of Bukittinggi City since 2000. This cart is always held at the Wirabraja Canteen Field of Bukittinggi City because it is located in the center of Bukittinggi City. Pedati was originally initiated by a community group calling itself the Youth Lovers of the United Nations to

${ }^{36}$ Zulfan Taufik, "From Negative to Positive PeaceL Strengthening the Role of Youth in Religious Peacebuilding in Bukittinggi, West Sumatra," AKADEMIKA: Jurnal Pemikiran Islam; Vol 25 No 2 (2020), October 4, 2020, https://e-

journal.metrouniv.ac.id/index.php/akademika/article/view $/ 2132$. 
establish national unity and integrity through a diversity and cultural richness approach and welcome the momentum of the Youth Pledge commemoration. Later, this party was also held in order to make the national tourism program a success.

The grand party also featured arts from 12 cities and regencies in West Sumatra, twelve teams from outside the province and abroad plus 18 associations in Bukittinggi City. Meanwhile, participants from outside the province of West Sumatra are Nanggroe Aceh Darussalam, North Sumatra, Riau, Riau Islands, Jambi, South Sumatra, Bangka Belitung and Lampung. In addition, the overseas arts team who have joined in every Pedati event include: Sri Heritage, Historic Melaka Bandaraya, Terengganu, Negeri Sembilan and the Universiti Malaysia Sarawak Cultural Team.

On the afternoon of the second day, the One Dasawarsa Pedati Nusantara performance will be filled with student creativity in the form of performances, competitions and festivals, including flower arranging competitions, brackets basiba clothes competition, Muslim fashion competitions, poetry reading competitions, Minang's song singer festivals, painting competitions, band festivals, reciprocated rhymes and others.

Meanwhile, Triarga Television will hold a workshop and presenter competition and act with its mini studio. Then Bukittinggi Television will display various works of the nation's children, both in the form of cultural arts and other works. RRI Muda Bukittinggi branch opened a mini studio to report various activities to Pedati Nusantara. The collaboration between PWI Representative of Bukittinggi with Century Media Advertising and Erison J Kambari Art Bukittinggi and www.korandigital.com will display photos of West Sumatra, Bukittinggi Tempo Doeloe, and photos of the current condition in Roder AC's tent.
In addition, the Pedati event was also enlivened by performing arts events by art groups. In Bukittinggi there are thirteen art groups, namely Gastarana, Sayyun Sastep, Puti Limo Jurai, Sakato, Ganto Minang, Mahligai, Tiger Silat College Singgalang Salimbado, Syofyani, Yellow Bamboo Shoots, Bambu Kuniang, Saluang Traditional Music Community, Satria Muda Indonesia and Mustika Minang.

Bukittinggi's Government has collaborated with Negeri Sembilan, Malaysia, namely increasing tourism and arts and culture. In support of this collaboration, Malaysia holds a Drum Party in Malacca and Bukittinggi is always invited. Bukittinggi's Government always facilitates Bukittinggi City art groups to take part in events organized by Malaysia.

\section{CONCLUSION}

The colonial policy towards religions in Indonesia was principally to safeguard their colonization and imperialization in the colonized lands. Discriminatory treatment in the social, educational, cultural, legal, and religious fields and a system of fighting against each other is a way to paralyze political forces and resistance. Although colonialism gave freedom to the implementation of religious teachings, and even paid attention to diversity, this was only a tactic to attract sympathy from religious circles, while their goal was to paralyze the soul of Indonesia.

In addition to the goal of power, the Dutch colonial carried out the spread of Christianity, especially to association groups, to strengthen power. Colonialist policies towards religions, in fact, contradicted various principles, especially in education. Starting from restrictions on religious teachers to the content of lessons, teaching permits, and the number of religious education institutions. Colonialists set double standards, for Muslims and Christians, and so on. Colonialism, which has existed for almost 4 centuries in the archipelago, has greatly influenced the religious patterns of the Bukittinggi people. For example, 
the entry of Christians to Bukittinggi was caused by the influence of colonialism. However, in religious understanding, Bukittinggi's people still adhere to the teachings of Islam, which are ingrained in the community. As the author has explained in the discussion above, before colonialism into Bukittinggi, many people in Bukittinggi were Muslim. So with a strong understanding of Islam in the Bukittinggi community, Islam is the supporter of the customs and culture developed in Bukittinggi. Islam is used as the basis for regulating social life.

The firm believer of Islam in Bukittinggi made it difficult for the colonialists to conquer Bukittinggi until finally the Colonial used its politics of fighting between the adat and the religious. The life of religious people, both internal and inter-religious in Bukittinggi, is generally conducive because there has never been an open conflict that has led to violence, but in fact, there has been a latent conflict between religious people groups due to differences in interests. Religious cases and social cases with religious nuances that have occurred so far, whether actual or not, prove that the latent conflict among religious people is quite intense. The emergence of new religious sects and socio-economic problems are cases of religious harmony among religious people in Bukittinggi, which actually color the dynamics of the community's religious life.

\section{BIBLIOGRAPHY}

Anggraini, Reni Dian. "Perlawanan Dan Pembebasan Kolonialisme Pada Tarekat Qadiriyah Wa Naqsyabandiyah (1888-1903)." Islam Transformatif: Journal of Islamic Studies 4, no. 2 (December 2020): 135. https://doi.org/10.30983/it.v4i2.3346.

Bakhtiar. Ranaah Minang Di Tengah Cengkeraman Kristenisasi. Jakarta: Bumi Aksara, 2005.

Bukittinggi, BPS Kota. "Bukittinggi Dalam Angka 2016.” Bukittinggi, 2016.

Dobbin, Christine. Gejolak Ekonomi, Kebangkitan Islam, Dan Gerakan Padri. Jakarta: Komunitas Bambu, 2008.

Fadila, Zikri. Penerbitan Minangkabau Masa Kolonial: Sejarah Penerbitan Buku Di Fort de Kock
(Bukittinggi) 1901-1942. Gre Publishing, 2018. Foucault, Michel. Power: The Essential Works of Michel Foucault 1954-1984: Essential Works of Michel Foucault 1954-1984. Administrative Science Quarterly. Vol. 3. London: Penguin Books Limited, 2002.

Graves, Elizabeth E. Asal Usul Elit Minangkabau Modren Respon Terbadap Kolonial Belanda Abad XIX/XX Terj. Novi Andri Dkk. Jakarta: Yayasan Obor Indonesia, 2007.

Hadler, Jeffrey. Sengketa Tiada Putus: Matriarkat, Reformisme Agama, Dan Kolonialisasi Di Minangkabau. Tingkap. Vol. 9. Jakarta: Freedom Institute, 2008.

Hakimy, Idrus. Rangkaian Mustika Adat Bersandi Syarak Di Minangkabau. 6th ed. Bandung: Pt. Remaja Rosdakarya, 2004.

Hamka. Antara Fakta Dan Khayal Tuanku Rao. Yogyakarta: Suara Muhammadiyah, 2008.

Hendri, Novi, and Hardi Putra Wirman. "The Radical Islamic Movements in West Sumatra: An Early Investigation and Mapping." Islam Realitas: Journal of Islamic \& Social Studies 6, no. 1 (2020): 100-118.

Mursal, Irhas Fansuri. "Surau Dan Sekolah: Dualisme Pendidikan Di Bukitinggi 19011942." Titian: Jurnal Imu Humaniora 2, no. 1 (2018): 100-115.

Pijper, G.F. Beberapa Studi Tentang Sejarah Islam Di Indonesia 1900-1950. Jakarta: Universitas Indonesia, 1985.

Said, Edward W. Orientalism. New York: Pantheon Books, 1978.

Steenbrink, Karel A. Beberapa Aspek Tentang Islam Di Indonesia Abad Ke-19. Jakarta: Bulan Bintang, 1984.

Sumanti, Solihah Titin. "Analisis Kebijakan Pemerintah Kolonial Belanda Terhadap Pendidikan Islam." Jurnal Ilmiah Sosialogi Agama (JISA) 1, no. 1 (July 2018): 44. https://doi.org/10.30829/jisa.v1i1.1791.

Suminto, H A. Politik Islam Hindia Belanda. Jakarta: Lembaga Penelitian Pendidikan dan Penerangan Ekonomi dan Sosial, 1985.

Suryanegara, Ahmad Mansur. Menemukan Sejarah: Wacana Pergerakan Islam Di Indonesia. 4th ed. Bandung: Mizan, 1998.

Taufik, Zulfan. "From Negative to Positive PeaceL Strengthening the Role of Youth in Religious Peacebuilding in Bukittinggi, West Sumatra." AKADEMIKA: Jurnal Pemikiran 
Islam; Vol 25 No 2 (2020), October 4, 2020. https://e-

journal.metrouniv.ac.id/index.php/akademi $\mathrm{ka} /$ article/view/2132.

Yulika, Febri. Epistemologi Minangkabau: Makna Pengetahuan Dalam Filsafat Adat Minangkabau. Yogyakarta: Gre Publishing, 2012. 